\title{
PENDIDIKAN TRANSFORMATIF MENUJU MASYARAKAT DEMOKRATIS
}

\author{
Mundzier Suparta \\ UIN Syarif Hidayatullah, Jl. Ir. H. Djuanda No. 95 Jakarta, \\ mundziersuparta@yahoo.com
}

\begin{abstract}
The basic argument that this paper tries to prove is that, education can be counter-productive to the most important value of humanity if it is run inappropriately. Given that value can be produced - in this modern time-by telecommunication and information technology, education cannot turn a blind eye on it. By implication, education cannot ignore modernity. It is this problem that this paper is concerned with. The paper is interested in discussing the idea of transformative education by relating it to many sources and factors of transformation. Modernity is certainly one of those. The paper-borrowing UNESCO—understands education as simply the learning to know, the learning to do, to be, and to live together. Consequently, education is all about adapting oneself to the environment in which he/she lives. It is in this context that education cannot escape modernity, for modernity has become the very part of human life and environment. And it is only through modernity-this paper argues-that education can be meaningful at least in democratic terms.
\end{abstract}

Keywords: Education, transformation, democracy.

\section{Pendahuluan}

Pemahaman tentang demokrasi secara filosofis menimbulkan banyak pertanyaan, khususnya dalam menentukan elemen-elemen utamanya. Bila merujuk pada elemen-elemen demokratis yang terdiri atas (1) Pengakuan kesetaraan antar-individu; (2) Nilai-nilai yang melekat pada individu mengatasi nilai-nilai yang melekat pada negara; (3) Pemerintah merupakan pelayan masyarakat; (4) Pengakuan seperangkat aturan-aturan hukum; (5) Pengakuan atas nalar dan pengalaman; (6) Pengakuan mayoritas terhadap hak-hak minoritas; dan (7) Adanya prosedur dan mekanisme demokratis sebagai cara mencapai 
tujuan bersama, ${ }^{1}$ maka sesungguhnya posisi masyarakat Indonesia dalam konteks demokrasi masih jauh dari harapan. Hal itu disebabkan belum diaplikasikannya elemen demokrasi secara komprehensif, sehingga diperlukan proses yang panjang untuk dapat merealisasikan nilai-nilai demokrasi dalam pendidikan secara utuh.

Perilaku masyarakat yang kurang demokratis terkadang menjelma di luar konteks yang positif, bahkan berimplikasi pada cost social dengan menghilangkan nilai-nilai luhur kemanusiaan. Dengan menerapkan pendidikan demokrasi diharapkan hal itu menjadi pijakan dalam peningkatan kualitas masyarakat Indonesia. Hanya saja yang perlu dipertanyakan, model pendidikan yang bagaimana yang mampu mendorong terciptanya masyarakat demokratis? Pertanyaan ini perlu dikemukakan karena banyak model pendidikan justru mengakibatkan perilaku yang tidak demokratis.

Di samping menghadapi persoalan model pendidikan, Indonesia juga menghadapi problematika budaya. Transformasi budaya semenjak Orde Baru ternyata telah banyak mengeliminir kemerdekaan dan hak asasi manusia, bahkan transformasi tersebut dapat mengenyampingkan nilai-nilai kemanusiaan untuk kepentingan pembangunan fisik an sich. Pendidikan telah dipisahkan dari konteks budaya bangsa. Pendidikan juga tidak lagi diarahkan untuk melahirkan manusia-manusia yang berbudaya, mempunyai identitas atau jati diri, dan menghasilkan manusia beradab, tetapi justru melahirkan manusia yang mudah tersinggung, tidak toleran, dan menganut budaya kekerasan.

Sebagai implikasinya, harus diakui bahwa pendidikan yang berjalan di Indonesia saat ini masih sekadar pada sosialisasi nilai. Dengan kata lain, pendidikan di Indonesia hanya sebatas mengantarkan peserta didik dan masyarakat pada batas mengetahui dan memahami sebuah konsep, sementara upaya internalisasi nilai belum bisa diaplikasikan secara proporsional. ${ }^{2}$

Dari paparan di atas diketahui telah terjadi kesenjangan antara visi pendidikan yang diharapkan dengan kenyataan yang ada. Pendidikan

1 Mahmoud Mohamed Taha, Syariah Demokratik, terj. Nur Rachman (Surabaya: Lembaga Studi Agama dan Demokrasi, 1996), 232-233.

2 Soedijarto, "Memahami Arah Kebijakan GBHN 1999-2004 tentang Pendidikan sebagai Upaya Mencerdaskan Kehidupan Bangsa dan Membangun Peradaban Negara Bangsa Indonesia”, makalah seminar nasional, Mencari Paradigma Baru Sistem Pendidikan Nasional Menghadapi Millenium Ketiga (Yogyakarta: IPSI dan Primagama, 1999), 1-2. 
bagi peserta didik adalah bagaimana mereka mampu mengonstruksi pengetahuan mereka dan mengaktualisasikannya dalam kehidupan sehari-hari tanpa harus merusak nilai-nilai budaya bangsa. Dalam kaitannya dengan konteks masyarakat demokratis, pendidikan diharapkan menjadi instrumen yang mampu menghasilkan warga negara yang bisa berperan aktif dalam menentukan bagaimana mereka bisa hidup bersama-sama di tengah masyarakat; bukan proses pendidikan yang justru menimbulkan narsisme, kegelisahan, perasaan tidak nyaman, penegasian, dan ketidaksadaran terhadap nilai-nilai bersama.

Tulisan ini berupaya mendeskripsikan model pendidikan transformatif yang dianggap menjadi salah satu alternatif untuk merealisir masyarakat demokratis. Pada tataran ini, pendidikan dipandang sebagai usaha sadar dan terencana untuk mewujudkan suasana belajar dan proses pembelajaran agar peserta didik mengembangkan potensi dirinya untuk menjadi warga negara yang memiliki kekuatan spiritual-keagamaan, pengendalian diri, kepribadian, kecerdasan, akhlaq mulia serta keterampilan dirinya, masyarakat, bangsa, dan negara. ${ }^{3}$

\section{Manusia dan Pendidikan}

Berbicara tentang pendidikan tidak bisa dilepaskan dari kajian tentang hakikat manusia, karena manusia adalah pelaku dari pendidikan itu sendiri, baik sebagai pendidik, anak didik, tenaga kependidikan, maupun sebagai penyelenggara dan pelaksana pendidikan. Dalam konteks kehidupan masyarakat, menurut Socrates (469 SM-399 SM), keadilan merupakan tujuan politik yang esensial bagi pemenuhan kecenderungan alamiah manusia sebagai makhluk individu dan makhluk sosial. Adapun tujuan pendidikan menurut Socrates adalah upaya untuk merangsang penalaran yang cermat dan disiplin mental yang akan menghasilkan perkembangan intelektual dengan standar moral yang tinggi. ${ }^{4}$ Dengan berfikir, manusia akan

3 Departemen Pendidikan Nasional Republik Indonesia, Undang-undang Republik Indonesia Nomor 20 Tabun 2003 tentang Sistem Pendidikan Nasinal (Jakarta: Biro Hukum dan Organisasi Sekretariat Jenderal Departemen Pendidikan Nasioal, 2003), 6.

${ }^{4}$ Dari tiga tipe tersebut, Socrates kemudian membagi masyarakat menjadi tiga kelas: 1) kelas pedagang yang bekerja mencari untung sebanyak-banyaknya (didasari oleh nafsu), 2) kelas prajurit yang bekerja memelihara keamanan dan ketertiban masyarakat (didasari oleh semangat), dan 3) kelas filsuf yang berfungsi sebagai penguasa (didasari oleh akal budi). Lihat Ramlan Surbakti, Memahami Ilmu Politik (Jakarta: PT. Grasindo, 1992), 24-25. 
mampu menertibkan, meningkatkan, dan mengubah dirinya sehingga ia dapat sungguh-sungguh mengetahui dan mengerti apa yang benar dan dapat menyadari segala konsekuensi akan perbuatan yang benar.

Berbeda dengan Socrates, Ibn Sînâ (980 M-1037 M) dalam konsepnya tentang manusia selalu berpijak pada tubuh dan jiwa (jasmani dan rohani) manusia. ${ }^{5}$ Dalam kajian filsafatnya, Ibn Sînâ menekankan bahwa unsur rohani atau jiwa mendapat perhatian lebih karena dianggap sebagai hakikat manusia yang sesungguhnya. Oleh karena itu, menurut Ibn Sînâ, sebagaimana dikutip oleh Hafiz Muthoharoh, dinyatakan bahwa pendidikan harus diarahkan kepada pengembangan seluruh potensi yang dimiliki seseorang menuju perkembangannya yang sempurna, yaitu perkembangan fisik, intelektual, maupun budi pekerti. ${ }^{6}$ Selain itu, pendidikan juga diarahkan pada upaya mempersiapkan seseorang agar dapat hidup bersama-sama di masyarakat dengan melakukan pekerjaan atau keahlian yang dipilihnya sesuai dengan bakat, kesiapan, kecenderungan, dan potensi yang dimilikinya ${ }^{7}$ sebagai wujud pengabdian diri dan mencari ridlâ Allah. ${ }^{8}$

Lain halnya dengan Ibn Miskawayh (934 M-1030 M) yang mengemukakan bahwa jiwa manusia mempunyai tiga daya, yaitu daya hewani (al-nafs al-bahimîyah) sebagai daya terendah, daya berani (al-nafs al-sabu'ŷah) sebagai daya pertengahan, dan daya berfikir (al-nafs alnatiqab) sebagai daya tertinggi. Ketiga daya ini merupakan unsur rohani manusia yang asal kejadiannya berbeda-beda. ${ }^{9}$ Konsep pendidikan menurut Ibn Miskawayh bertumpu pada pendidikan akhlaq. Karena itu, tujuan pendidikan menurutnya harus bersifat universal, yakni mencakup kebahagian manusia secara universal. ${ }^{10}$

Berbeda lagi dengan Thomas Hobbes (1588-1679), yang memandang manusia sebagai makhluk yang memiliki "watak agresif' dan

5 T. J. De Boer, Târikh al-Falsafah fì al-Islâm (Kairo: Lajnah al-Ta'lif wa al-Tarjamah, t.th.), 65; Harun Nasution, Falsafah dan Mistisisme dalam Islam (Jakarta: Bulan Bintang, 1985), 34-38.

6 Hafiz Muthoharoh, "Konsep Pendidikan Islam Menurut Ibnu Sînâ", dalam http://alhafizh84.wordpress.com/2012/03/03/2123/ (15 Maret 2013).

${ }^{7}$ Ibid.

8 Suwito dan Fauzan (eds.), Sejarah Pemikiran Para Tokoh Pendidikan (Bandung: Angkasa, 2003), 109-126.

${ }^{9}$ Ibn Miskawayh, Tạ̣dhîb al-Akblâq (Beirut: Manshûrat Dâr al-Maktabah al-Hayât, $1398 \mathrm{H}), 63$.

10 Abuddin Nata, Filsafat Pendidikan Islam (Jakarta: Logos, 1997), 12. 
"berpotensi jahat". Sedangkan menurut Jean-Jacques Rousseau (17121778) dalam keadaan alamiah manusia pada dasarnya baik, atau ia memiliki apa yang diistilahkan Rousseau sebagai "kebaikan-kebaikan alamiah" (natural Goodness). Rousseau, sebagaimana yang ditulis Franz Magnis-Suseno, mengidealisir manusia yang liar, tetapi baik. Menurut Magnis-Suseno, manusia alamiah adalah manusia yang mementingkan keutamaan hidup, altruis, tidak artifisial, dan bebas dari pengaruh kekuasaan orang lain, karena secara esensial manusia memiliki kesamaan kedudukan di dunia ini. Manusia dalam keadaan alamiah adalah makhluk yang belum mengerti nilai-nilai baik dan buruk dalam arti moralitas yang kita pahami, sebab mereka tidak terdidik dalam struktur sosial yang disupervisi oleh moralitas. ${ }^{11}$

Melalui kajian tentang konsep manusia dan pendidikan di atas, dapat diketahui bahwa pendidikan sesungguhnya ingin menempatkan manusia sebagai sebagai subjek pendidikan yang otonom dan memiliki ragam potensi yang dapat dikembangkan untuk menjadi manusia ideal.

Penulis di sini menganggap bahwa pendidikan transformatif adalah salah satu instrumen penting demi terealisirnya masyarakat demokratis. Mengingat pentingnya model pendidikan tersebut, maka penting untuk menyiapkan peserta didik untuk menjadi warga negara yang aktif. ${ }^{12}$ Di sinilah peran institusi pendidikan-mulai dari satuan pendidikan dasar, menengah, dan tinggi-untuk memberikan sosialisasi terhadap nilai-nilai perenial dan sekaligus melatih warga negara untuk mampu hidup secara berdampingan dengan anggota masyarakat lain secara damai dan saling menghargai.

\section{Model Pembelajaran Transformatif}

Model pembelajaran transformatif didasarkan pada paradigma konstruktivis yang mengaktualisir setiap individu untuk dapat membangun pengetahuan melalui pengalaman mereka di dunia. Pembelajaran transformatif berimplikasi pada proses perolehan pengetahuan yang dikonstruksi secara sosial oleh sekelompok individu. Di antara sarjana yang banyak menerbitkan teori pembelajaran transformatif adalah Jack Mezirow (1. 1927). Dia sering mendasarkan idenya dalam bidang ini pada teori kritis Jürgen

${ }^{11}$ Franz Magnis-Suseno, Etika Politike (Jakarta: PT. Gramedia, 1994), 238.

12 Biren (Ratnesh) A. Nagda, Patricia Gurin, Gretchen E. Lopez, "Transformative Pedagogy for Democracy and Social Justice", Journal of Race Ethnicity and Education, Vol. 6, No. 2 (July 2003), 165. 
Habermas (1. 1929). Di samping dipengaruhi Habermas, karya Mezirow juga terinspirasi melalui teori Paulo Freire (1921-1997) tentang penyadaran (conscientization) yang juga dia anggap sebagai proses paralel untuk model pembelajaran transformatif yang dia uraikan. ${ }^{13}$

Pembelajaran transformatif sendiri mencoba untuk menumbuhsuburkan kesadaran individu tentang dirinya sendiri sebagaimana terletak dalam kekuatan politik dan ekonomi yang lebih besar. Apa yang Freire sebut sebagai penyadaran (conscientization) di atas merupakan proses pemberian fasilitas pemahaman dan rasa keberhasilan bahwa hubungan dominasi dan keterasingan itu dapat diubah. Tujuan pembelajaran transformatif bukan hanya untuk mentransformasi pribadi, tetapi juga untuk mentransformasi sosial sehingga individu dapat menjadi produsen kreatif bagi dirinya dan masyarakat serta hubungan politik dan ekonomi. ${ }^{14}$

Masih menurut Mezirow, pembelajaran transformatif merupakan proses memengaruhi perubahan dalam kerangka acuan (frame of reference) yang konkret. Sepanjang hidup, kita mengembangkan ragam konsep, nilai, perasaan, tanggapan, dan asosiasi yang membentuk pengalaman hidup kita. Kerangka acuan itulah yang membantu kita untuk memahami pengalaman kita di dunia ini. Pengalaman hidup itu sendiri menurut Mezirow, terdiri dari dua dimensi, yakni kebiasaan pikiran (babit of mind) dan sudut pandang (point of view). Kebiasaan pikiran kita sangat luas dan merupakan kebiasaan yang dapat diartikulasikan melalui sudut pandang. Contohnya, konsumerisme adalah kebiasaan pikiran yang diartikulasir melalui sudut pandang tentang pembelian produk. Sudut pandang pada umumnya lebih mudah diakses daripada kebiasaan pikiran, yang digambarkan lebih bertahan lama dan lebih sulit untuk berubah dibandingkan sudut pandang. Pembelajaran transformatif berkaitan dengan cara mengubah kerangka acuan melalui refleksi kritis terhadap kebiasaan pikiran dan sudut pandang. Sebagai contoh, merefleksikan pola konsumsi dan produksi secara kritis dapat berdampak pada perilaku konsumtif kita sendiri. ${ }^{15}$ Melalui refleksi kritis atas berbagai bias dan asumsi, kita bisa

13 Janet Moore, "Is Higher Education Ready for Transformative Learning?: A Question Explored in the Study of Sustainability", Journal of Transformative Education, Vol. 3, No. 1 (January 2005), 82.

${ }^{14}$ Elizabeth A. Lange, "Transformative and Restorative Learning: A Vital Dialectic for Sustainable Societies”, Adult Education Quarterly, Vol. 54, Iss. 2 (Feb 2004), 122.

${ }^{15}$ Moore, "Is Higher Education Ready", 82. 
memindahkan pemahaman, mengubah pandangan dunia, dan menciptakan pengalaman belajar transformatif. Untuk mengikuti contoh konsumsi di atas, kita dapat datang untuk memahami mengapa kita mengonsumsi apa yang kita lakukan. ${ }^{16}$

Siklus dasar transformasi diawali melalui serangkaian refleksi pada sudut pandang dan kebiasaan pikiran untuk mengubah kerangka acuan seseorang. Tujuan pembelajaran transformatif adalah merevisi asumsi lama dan cara menafsirkan pengalaman melalui refleksi kritis dan refleksi diri. Hal ini senada dengan pendapat Patricia Cranton yang megatakan bahwa pembelajaran kelompok transformatif mirip dengan definisi pembelajaran kelompok partisipatif. Dalam penjelasannya terhadap teori Mezirow, Cranton membahas penekanan pada refleksi diri dan tanggung jawab siswa untuk tujuan pembelajaran. Cranton membahas asumsi yang mendasari bahwa kelompok belajar transformatif akan menyebabkan perubahan individu dan sosial. Dalam interpretasinya, peserta dapat dan akan terlibat dalam aksi kolektif setelah menetapkan tujuan kolektif dalam kelompok. Para pendidik dalam situasi ini bertanggung jawab untuk menciptakan lingkungan yang kondusif dan terbuka untuk refleksi diri. Tujuan utama dari pembelajaran transformatif adalah untuk memberdayakan individu untuk mengubah perspektif mereka. ${ }^{17}$

\section{Karakteristik Masyarakat Demokratis}

Setelah berbicara tentang konsep pembelajaran transformatif, penulis sekarang akan masuk pada konsep masyarakat demokratis. Menurut Socrates, suatu rezim atau masyarakat dapat dikatakan adil, manakala setiap kelas sosial yang ada di dalam masyarakat melaksanakan fungsinya secara maksimal dan bekerja secara harmonis di bawah pengarahan sang filsuf-raja yang bijaksana. ${ }^{18}$ Dalam negara demokrasi, kebebasan individu dan pluralitas politik adalah dewa yang diagungkan. Semua warga negara mempunyai kebebasan untuk mengekspresikan aspirasi dan idealisme politiknya tanpa harus merasa khawatir akan adanya intervensi negara terhadap hak dan kebebasannya itu.

Dalam istilah Plato (428/427 SM-348/347 SM), demokrasi itu penuh sesak dengan kemerdekaan dan kebebasan berbicara dan setiap

\footnotetext{
${ }^{16}$ Ibid., 83.

17 Ibid.

18 Berdasarkan asumsi adanya kesejajaran antara cara hidup manusia dan struktur masyarakat itu, Socrates membagi jenis rezim ke dalam lima tipe: 1) Aristokrasi, 2) Timokrasi, 3) Oligarki, 4) Demokrasi, dan 5) Tirani. Lihat Surbakti, Memahami, 35.
} 
orang dapat berbuat sekendak hatinya. Anarkisme, konfrontasi, dan kekerasan baik yang bersifat individual maupun massal dibenarkan atas nama kebebasan dan persamaan hak. Penjungkirbalikkan massal terhadap moralitas dan akal budi dibenarkan dengan alasan kebebasan. ${ }^{19}$

Menurut Thomas Hobbes, dalam teorinya tentang negara mengatakan bahwa yang berlaku dalam masyarakat adalah hukum alam atau ius naturalis, di mana tiap-tiap individu mencoba bertahan hidup walaupun dengan menyerang orang lain. Tujuan dari undangundang tersebut adalah menciptakan perdamaian, dengan cara membatasi kemerdekaan setiap orang, melalui pengangkatan seorang raja yang kekuasaannya bersifat mutlak. Kekuasaan yang dimiliki oleh raja itu adalah refleksi dari kekuasaan negara, di mana individu warga negara harus rela menyerahkan hak-haknya, supaya kepentingan keamanan dan perdamaiannya dapat dijamin dalam jangka panjang.

Selanjutnya, Jean-Jacques Rousseau, dalam karya The Social Contract, menganalisis masyarakat demokratis pada dua aspek penting, yakni state of nature (manusia alamiah dan kebebasan) dan "teori kontrak sosial". Menurut Craston, Rousseau sangat berhutang budi pada pemikiran Thomas Hobbes dan para ahli hukum seperti Grotius, Pupendrof, Barbeyrec, Berlamaqui, dan John Locke ketika ia menyusun $d u$ Contract Social tahun $1762 .{ }^{20}$ Dalam teori kontrak sosial yang menelaah tentang pembentukkan kekuasaan negara, eksistensi negara itu, menurut Rousseau, tidak lebih dari suatu perjanjian sosial, di mana individu-individu dalam suatu masyarakat bersepakat untuk menyerahkan sebagian hak-hak, kebebasan dan kekuasaan yang dimilikinya kepada suatu kekuasan yang bersama (common power). Kekuasaan bersama ini kemudian yang dinamakan negara, yang mendapatkan mandat dari rakyat untuk mengatur, mengayomi dan menjaga keamanan maupun harta benda mereka. Kedaulatan negara akan tetap absah sepanjang negara tetap menjalankan fungsi-fungsinya sesuai dengan kehendak rakyat yang memberikan mandat kepadanya.

Di sinilah kemudian pentingnya pendapat Socrates yang menekankan fungsi pada setiap kelas sosial serta kerjasama yang harmonis agar terbentuk masyarakat yang adil. Oleh karenanya, menjadi penting

19 Tim Redaktur, "Pemikiran Plato tentang Negara", Majalah Filsafat Driyakarya, Th. 22, No. 9 (1993/1994).

${ }^{20}$ Dikutip dari Suhelmi, Pemikiran Politik Barat. Kajian Sejarah Perkembangan Pemikiran Negara, Masyarakat, dan Kekuasaan (Jakarta: Darul Falah, 1999), 194. 
untuk membebaskan setiap individu untuk berpendapat dan berkehendak. Akan tetapi, agar kebebasan tersebut tidak disalahgunakan dan dapat merugikan orang lain, Hobbes menyarankan pentingnya undang-undang sebagai produk hukum untuk menciptakan perdamaian, dan membatasi kemerdekaan individu yang dapat merugikan orang lain. Untuk menjalankan produk undangundang tersebut, menurut Rousseau harus ada kontrak sosial yang berisi kesepakatan agar tidak ada pelanggaran kekuasaan terhadap orang yang diberikan mandat atau kepercayaan oleh rakyat.

\section{Kurikulum Pendidikan Transformatif}

Abad ke-21 disebut pula dengan milenium ketiga dan abad globalisasi. Abad, yang melanjutkan kedigdayaan masa modern, tersebut ditandai oleh beberapa indikasi seperti kemajuan iptek, semakin besar materialisme, kompetisi global, dan persaingan bebas. Globalisasi adalah kata yang digunakan untuk memaknai "bersatunya" berbagai negara dalam satu entitas. Secara istilah globalisasi, sebagaimana dikatakan oleh Azyumardi Azra yang dikutip dari alRounbaie, berarti perubahan-perubahan struktur dalam seluruh kehidupan negara bangsa yang mempengaruhi fundamen-fundamen dasar pengaturan hubungan manusia, organisasi-organisasi sosial dan pandangan-pandangan dunia. Sejalan dengan pendapat ini, para pengamat sosial menyatakan bahwa globalisasi ditandai dengan adanya revolusi informasi yang maha dahsyat dan juga ditandai oleh tingginya prestasi umat manusia dalam teknologi informatika. Pada gilirannya hal ini tidak hanya membawa kemudahan-kemudahan dalam proses komunikasi antar-bangsa, tetapi juga diperkirakan akan memicu munculnya akulturasi asimetris, yaitu pola hubungan yang timpang antara negara-negara maju dan berkembang. Dalam pola hubungan ini negara-negara maju akan mendominasi negara-negara berkembang, tidak hanya dalam bidang ekonomi dan teknologi, tetapi juga dalam bidang-bidang kehidupan umat manusia lainnya, seperti politik, militer, budaya, pendidikan, dan bidang-bidang kehidupan manusia. Perkembangan dan perubahan tersebut tidak dapat dielakkan dan pasti akan memicu munculnya persaingan antar-bangsa yang semakin keras dan tajam, serta membuat jurang ketimpangan semakin lebar. Pesatnya kemajuan teknologi telekomunikasi dan transportasi memungkinkan terjadinya penyebaran informasi dan nilai-nilai secara global di samping juga akan membuat semakin menciutnya jarak dan waktu. 
Dalam bidang ekonomi, era globalisasi tidak hanya mendorong terjadinya percepatan dalam perdagangan global, tetapi juga memicu percepatan kemajuan pendidikan yang didasarkan pada ekonomi (knowledge based on an economy). Kemapanan dalam bidang ekonomi juga akan memberikan implikasi positif pada kemajuan ilmu pengetahuan dan teknologi, sosial, budaya, dan bahkan kemajuan dalam bidang politik, karena dengan kemapanan tersebut berbagai penelitian dan riset dalam berbagai bidang dapat dengan mudah dilakukan. Selanjutnya Azra meyatakan bahwa hegemoni ekonomi dan sainsteknologi jelas bukan persoalan sederhana. Hegemoni dalam bidangbidang ini bukan hanya menghasilkan ekonomi dan sains-teknologi, tetapi ia juga memasuki bidang-bidang lain seperti intelektual, sosial, nilai-nilai, gaya hidup, dan seterusnya. Globalisasi Coca-cola atau McDonald, bukan sekadar proses ekspansi ekonomi, tetapi juga gaya hidup, dengan segala implikasinya. Globalisasi "McDonald", misalnya menimbulkan perubahan dalam pola dan jenis makanan yang dikonsumsi masyarakat. Perubahan ini pada gilirannya menimbulkan implikasi-implikasi tertentu bagi kesehatan masyarakat. Dalam bidang telekomunikasi misalnya juga telah memunculkan globalisasi "kotak segi empat" yang bernama televisi di mana melalui tayangannya telah terjadi proses ekspansi dan penetrasi nilai-nilai semacam "keserbalonggaran" (permissiveness) hubungan antara laki-laki dan perempuan, kehidupan yang serba materialistik dan hedonistik, atau kultur kekerasan yang semuanya tidak cocok dengan nilai-nilai budaya dan agama masyarakat Indonesia. ${ }^{21}$

Bangsa dan negara yang menguasai teknologi informatika dan memiliki kualitas, daya saing, dan keunggulan dalam berbagai bidang tersebut yang akan memenangkan pertarungan dan pasti mampu bertahan dan menguasai dunia. Negara-negara Barat dan non-Muslim pada umumnya telah memenangkan kontestasi ini. Sebaliknya, bangsa dan negara yang lemah dan tidak memiliki kemampuan berkompetisi akan menjadi makanan empuk negara-negara maju dan pasti akan membuat negara dan bangsa tersebut menjadi bangsa yang termarjinalkan, miskin, dan kehilangan kesempatannya menjadi bangsa yang luhur. Kondisi ini secara umum ada pada negara-negara berkembang di mana mayoritas masyarakatnya memeluk agama Islam,

21 Azyumardi Azra, Pendidikan Islam: Tradisi dan Modernisasi Menuju Mellenium Baru (Jakarta: Logos, 2002), 44-45. 
termasuk Indonesia. ${ }^{22}$ Bayangan seperti itu seharusnya diperlukan keadaan masyarakat yang siap untuk mengarungi globalisasi yaitu dengan kesiapan kehebatan sistem pendidikan yang mampu menelorkan manusia-manusia global yang setiap saat siap bersaing. Namun pertanyaannya, "apakah sistem pendidikan di Indonesia sudah siap ke arah tersebut”.

Untuk mengantisipasi abad ke-21, UNESCO (United Nation Educational, Scintific and Cultural Educational) telah merumuskan visi dasar pendidikan, yaitu learning to think, learning to know, learning to do, learning to be, dan learning to live together. ${ }^{23}$ Terhadap visi ini, Qadri A. Azizi menjelaskan sebagai berikut:

a. Learning to think (belajar bagaimana berfikir), atau learning to know. Kontinuitas berfikir secara rasional bukan perkara yang mudah. Visi ini diharapkan agar seseorang dapat independen, gemar membaca, selalu belajar, mempunyai pertimbangan rasional tidak semata-mata emosional dan selalu ingin tahu segala hal. Banyak ayat al-Qur'ân dan Hadith Nabi mengajarkan untuk berfikir dan belajar. Kata 'aql dengan varian bentuknya dalam al-Qur'ân merupakan teguran dan peringatan Allah agar manusia selalu mengaktualisir akalnya. Selain kata 'aql masih banyak dijumpai dalam al-Qur'ân yang memberikan tuntutan untuk selalu mempergunakan akalnya, seperti kata-kata tatadabbarûn, afalâ tanz̧urîn, dan lain-lain.

b. Learning to do (belajar hidup atau belajar bagaimana berbuat). Pendidikan dituntut untuk menjadikan anak didik setelah menamatkan pendidikannya untuk mampu berbuat dan memperbaiki kualitas hidupnya, sesuai dengan tantangan yang ada. Dengan ketatnya kompetisi global, setiap individu dituntut untuk semakin profesional dan mempunyai skill untuk mampu berkompetisi. Agama Islam banyak menyebutkan perintah Allah kepada hambaNya agar beramal saleh. Amal saleh (perbuatan/karya yang baik) adalah salah satu syarat agar seseorang tidak berada pada tempat yang paling rendah (asfal al-sâfilinn). Lebih dari itu, ada juga tantangan Allah kepada manusia agar mengelola bumi seisinya.

22 Disarikan dari Hasbi Indra, Pendidikan Islam Menuju Globalisasi (Jakarta: Ridamulia, 2005), 55-87.

23 Soedijarto, Pendidikan Nasional sebagai Wahana Mencerdaskan Kebidupan Bangsa dan Membangun Peradaban Negara-bangsa: Sebuah Usaha Memahami Makna UUD 45 (Jakarta: CINAPS, 2000), 85. 
Namun, dalam waktu bersamaan, Allah juga mengecam dan melarang hamba-Nya berbuat kerusakan di atas bumi. Di samping skill, dibutuhkan ketekunan, kerja keras, tanggungjawab, dan disiplin untuk dapat berkompetisi secara ketat. Ajaran Islam mengecam terhadap orang-orang yang meminta-minta, tanpa berkarya/bekerja, meskipun juga menganjurkan untuk berbuat santun kepada para pengemis.

c. Learning to be (belajar bagaimana tetap hidup, atau sebagai dirinya). Untuk dapat tetap hidup diperlukan pula "introspeksi". Dalam bahasa agama kita, hal ini akan menghasilkan sikap introspeksi, sikap memahami dirinya sendiri, sadar kemampuan diri sendiri, dan nantinya akan mampu menjadikan dirinya mandiri. Dengan demikian, seseorang yang telah menjalankan hal ini akan terhindar dari sikap dengki, hasud, serakah, dan sifat radhâil (perilaku tercela) lainnya. Melalui sikap introspektif, seseorang akan menghindarkan dirinya dari sikap mengkhayal di luar batas kemampuannya. Dengan sikap ini pula, ia akan menghindarkan dirinya dari sikap serakah, tamak, ketergantungan kepada orang lain dan sesamanya. Hasil akhirnya akan mandiri dan menyadari realitas.

d. Learning to live together (belajar untuk hidup bersama). Kebersamaan akan mudah terwujud jika kita bersedia menerima kenyataan akan adanya perbedaan. Pemahaman terhadap pluralitas pemikiran akan menyadarkan kita akan nilai-nilai universal seperti HAM, demokrasi, dan seterusnya. Abad ke-21 adalah abad global sekaligus plural. Dalam masyarakat Indonesia dikenal istilah SARA yang pada dasarnya netral dan banyak mengandung nilai positif. Oleh karena itu, cara yang harus dipilih adalah kesanggupan untuk belajar hidup berdampingan bersama-sama, tanpa harus uniformity; saling memanfaatkan potensi positifnya untuk saling menopang kehidupan bersama. ${ }^{24}$

Visi tersebut kiranya cukup relevan dengan kondisi peserta didik jika dilihat dari aspek kognitif, afektif, dan psikomotorik. Namun persoalannya untuk ke arah tersebut ada beberapa hambatan yang memang harus segera diperbaiki di antaranya kurikulum dan metode. Sistem pendidikan yang menjadikan peserta didik sebagai objek telah memberangus potensi kritis. Selain itu kurangnya keterampilan yang

24 Ahmad Qodri A. Azizy, Pendidikan (Agama) untuk Membangun Etika Sosial: Mendidik Anak Sukses Masa Depan, Pandai, dan Bermanfaat (Semarang: Aneka Ilmu, 2002), 30-34. 
dimiliki peserta didik akan membuat peserta didik kurang memiliki keahlian setelah menamatkan pendidikan. Ini mengakibatkan peserta didik tidak dapat bersaing dan menjadi meningkatnya angka pengangguran di Indonesia.

Sementara di belahan dunia yang lain, gagasan-gagasan Paulo Freire dan Ivan Illich menimbulkan gaung dan sambutan cukup besar. Freire menegaskan bahwa pembelajaran harus diperlakukan sebagai partisipasi aktif dan pemikiran-pemikiran peserta didik harus menjadi acuan dalam perumusan bahan yang akan diajarkan. Hal ini dapat dilihat ketika Freire bicara tentang pendidikan model bank. Menurutnya, pendidikan model bank ini hanya akan melahirkan sikap mematikan daya kreatif murid dan menjadikan mereka sebagai objek. Karenanya, pendidikan yang baik, menurutnya, adalah pendidikan model problem-posing (mengajukan masalah). Pedidikan model ini yang menganggap murid sebagai subjek. Guru selalu menyerap baik ketika dia mempersiapkan bahan pelajaran maupun ketika dia berdialog dengan para murid. ${ }^{25}$

Pendapat Freire ini memang cukup signifikan karena selama ini pendidikan hanya sebagai proses transfer ilmu pengetahuan, yang menyebabkan peserta didik pasif dan mengikuti apa yang diberikan oleh sang pendidik. Pendidikan yang seperti ini memang mematikan kreativitas berpikir peserta didik dan mereka tidak bisa berkreasi serta berinovasi. Untuk itu pendidikan yang besifat teacher center harus diubah menjadi student center. Untuk mendukung hal tersebut kurikulum juga harus dipersiapkan dan harus disesuaikan dengan kebutuhan peserta didik, karena kurikulum yang tidak sesuai dengan kebutuhan peserta didik akan mengakibatkan pendidikan yang tidak mempunyai arah tujuan yang jelas.

Selain harus sesuai dengan kebutuhan peserta didik, kurikulum juga harus melihat kondisi peserta didik tinggal, karena kurikulum yang sesuai dengan kebutuhan peserta didik dan disesuaikan dengan daerahnya akan membantu peserta didik mentransformasikan dalam mengembangkan dan membangun lingkungannya ke arah yang lebih baik.

Dalam menerapkan sebuah kurikulum, hendaknya ada sebuah proses dialog yang menjadi alat komunikasi yang efektif, karena dengan tatap muka akan timbul ikatan emosional antara peserta didik

25 Poulo Freire, Pendidikan Kaum Tertindas, terj. Muhdi Rahayu (Jakarta: LP3ES, 2013), 61-66. 
dan pendidik. Selain itu juga akan memberikan umpan balik antara peserta didik dengan pendidik, di sinilah terjadinya proses dialektika untuk membentuk pengetahuan baru, keterampilan, dan kerja sama.

Ada tiga hal yang penting yang akan ditransfer melalui pendidikan, yaitu nilai (values), pengetahuan (knowledge), dan keterampilan (skill), di mana seni termasuk di dalamnya. Oleh karena itu, tujuan pendidikan juga beragam, sesuai dengan bagaimana masyarakat atau negara mendefinisikkan pendidikan dan bagaimana pula filsafat hidupnya. Untuk itu menyitir pendapat James Maclellan, dalam Philosophy of Education, yang menegaskan Education does not designate any particular activities or pratices but rather indicates a kind of purfose or intention with one might engage in pedagogical activities of various sorts, where pedagogical activities means those designed to produce learning in another. (Pendidikan tidak menunjuk pada aktivitas praktik tertentu, namun [ia] lebih mengindikasikan bentuk tujuan atau niat dengan [cara] seseorang dapat menggunakan berbagai macam rupa aktivitas yang berkaitan dengan pendidikan, di mana aktivitas-aktivitas ini berarti hal-hal yang direncanakan untuk menghasilkan pembelajaran pada yang lain. Tujuan pendidikan sebagai hal yang lebih dominan dalam pendidikan).

Sebagaimana yang juga diungkapkan oleh Breiter bahwa Education is a metter of purpose and focus. To educate a child is to act with purpose of influencing the child's development as a whole person.what you do may vary. You may teach him, you may play with him, you may structur his environment, you may censor his television viewing, or you may pass laws to keep him out of bars. (Pendidikan adalah persoalan tujuan dan fokus. Mendidik anak berarti bertindak dengan tujuan agar mempengaruhi perkembangan anak sebagai individu yang utuh. Apa yang dapat anda lakukan itu bisa dengan bermacam-macam cara seperti bermain dengannya, mengatur lingkungannya, menyensor tontotan televisinya, atau anda dapat memberlakukan hukum agar dia jauh dari penjara). ${ }^{26}$

Pada pola belajar yang berkembang saat ini, seorang anak didik tidak pernah dididik atau dibiasakan untuk kreatif dan inovatif serta diorientasikan pada keinginan seorang anak didik untuk tahu (curiosity). Kurangnya perhatian terhadap aspek ini menyebabkan anak hanya dipaksa menghapal dan menerima apa yang dipaketkan guru. Anak tidak diberi ruang untuk berpikir dan berinovasi dan berkreasi, apalagi sampai menemukan sesuatu yang baru (discovery).

26 James Maclellan, Philosophy of Education (Englewood Cliffs: Prentice-Hall, 1976), 18. 
Menurut teori belajar Alfred N. Whitehead (1861-1947), pendidikan yang baik adalah memberikan kesempatan dan pengalaman anak pada indahnya penemuan baru (the joy of discovery). Pengalaman ini baru dapat terealisir jika pembelajaran yang berlangsung di kelas atau di sekolah memberikan gerak bebas bagi setiap murid untuk menciptakan rasa ingin tahu (curiousity). ${ }^{27}$ Dengan kata lain, pendidikan harus dilaksanakan secara demokratis.

Menurut Dewey, pendidikan demokratis adalah pendidikan yang mempunyai gagasan persamaan. ${ }^{28}$ Persamaan adalah perlakuan seseorang terhadap orang lain dalam sebuah kelompok untuk memberikan kesempatan kepada setiap anggota kelompok guna menerima dan mengambil sesuatu pelajaran dari orang lain. ${ }^{29}$ Musdah Mulia, dalam bukunya Muslimah Perempuan Pembaharu Keagamaan Reformis, menyatakan bahwa pendidikan yang demokratis itu ditandai dengan keikutsertaan pelaku pendidikan dan peserta didik secara bersama-sama dalam pengambilan keputusan untuk keperluan dirinya. ${ }^{30}$ Perbedaan gender sesungguhnya merupakan hal yang biasa saja sepanjang tidak menimbulkan ketimpangan-ketimpangan gender. Akan tetapi, realitas di masyarakat menunjukkan bahwa perbedaan gender telah melahirkan beragam ketimpangan atau ketidakadilan, baik bagi laki-laki, dan terlebih lagi bagi perempuan. ${ }^{31}$

Bagaimana mungkin dalam pendidikan akan tercipta persamaan kalau pendidikan yang feodalistik dan paternalistik masih eksis. Diperlukan kesadaran yang tinggi oleh semua pihak, terutama pemangku pendidikan untuk mengubah hal itu semua. Untuk itu pentingnya pendidikan yang berwawasan gender adalah untuk mengubah bentuk ketidakadilan yang terjadi menjadi kesetaraan atau persamaan menuju kesetaraan gender yang lebih demokratis.

Menurut Syahraini, pendidikan yang dibutuhkan adalah model pendidikan yang demokratis, partisipatif, dan humanis. Untuk

\footnotetext{
27 Alfred N. Whitehead, The Aims of Education and Other Essays (New York: The Free Press, 1957).

28 John Dewey, Culture and Freedom, terj. A. Rahman Zainudin (Jakarta: Yayasan Obor Indonesia, 1998), viii.

${ }^{29}$ John Dewey, Democracy and Educational: An Introduction to the Philosophy of Education (New York: The Macmillan Company, 1964), 84.

${ }^{30}$ Musdah Mulia, Muslimah Perempuan Pembaharu Keagamaan Reformis (Bandung: Mizan Media Utama, 2005), 119.

${ }^{31}$ Musdah Mulia, "Pendidikan Berwawsan Gender", al-Hikmah, Vol. 3, No. 4 (April 2003), 48.
} 
mendukung model pendidikan demokratis, Paul Suparno merekomendasikan beberapa hal, yaitu menghindari indoktrinasi, menghindari paham "hanya ada satu nilai saja yang benar", memberi kebebasan bagi anak untuk berbicara, memberi peluang bahwa siswa boleh berbuat salah, mengembangkan cara berfikir ilmiah dan kritis, dan berilah kesempatan yang luas kepada siswa untuk bermimpi dan berfantasi. $^{32}$

Oleh karena itu, pendidikan harus memberikan kesempatan yang sama kepada setiap anak untuk mendapatkan pendidikan di sekolah sesuai dengan kemampuannya. Pengertian demokratis di sini mencakup arti baik secara horizontal maupun vertikal. Maksud demokrasi secara horizontal adalah bahwa setiap anak tanpa terkecuali mendapatkan kesempatan yang sama untuk menikmati pendidikan sekolah. Hal ini sebagaimana yang tercermin pada UUD 1945 pasal 31 ayat 1 yaitu: "Tiap-tiap warga negara berhak mendapat pengajaran". Sementara itu, demokrasi secara vertikal dinyatakan bahwa setiap anak mendapat kesempatan yang sama untuk mencapai tingkat pendidikan sekolah yang setinggi-tingginya sesuai dengan kemampuannya.

\section{Implementasi Pendidikan Transformatif}

Sejak masa Thomas Jefferson, pendidikan dilihat sebagai alat untuk menyiapkan manusia-manusia muda untuk warga negara yang demokratis. Institusi pendidikan didudukkan sebagai alat 'sosialisasi' bagi peserta didik yang diorientasikan untuk warga negara yang demokratis. Akan tetapi, sejumlah ahli pendidikan kritis berargumentasi bahwa institusi pendidikan dapat memainkan peranan penting dalam mempromosikan pemahaman alternatif tentang demokrasi dan dengan demikian dapat membantu membangun masyarakat yang lebih demokratis dan adil. ${ }^{33}$

Untuk bisa berpartisipasi pada ruang demokrasi publik, peserta didik perlu dibekali sejumlah kompetensi dan worldview untuk memahami dan merespons dilema personal maupun sosial. Institusi pendidikan dapat memberikan kesempatan unik bagi peserta didik untuk mengembangkan keterampilan berpikir tinggi (bigher order thinking skills) serta keterampilan relasional dengan orang yang

\footnotetext{
32 Syahraini Tambak, Membangun Bangsa Melalui Pendidikan: Gagasan Pemikiran dalam Mewujudkan Pendidikan Berkualitas untuk Kemajuan Bangsa Indonesia (Yogyakarta: Graha Ilmu, 2013), 36-38. Lihat juga Momon Sudarma, Mengembangkan Keterampilan Berpikir Kreatif (Jakarta: PT Raja Grafindo Persada, 2013), 197-200.

${ }^{33}$ Nagda, et al., “Transformative Pedagogy”, 165-166.
} 
berbeda dari diri mereka sendiri. Praktik pendidikan transformatif akan membantu siswa melihat masalah dalam konteks sosial yang lebih luas, mengasah kemampuan mereka untuk penyelidikan mendalam dan kritis, mempertimbangkan berbagai pandangan dan perspektif dalam dialog dengan orang lain, dan terlibat dalam pergaulan yang dapat mempersiapkan mereka sebagai warga negara yang demokratis. Dalam konteks inilah institusi pendidikan-mulai dari satuan pendidikan dasar, menengah, dan tinggi-memiliki peran strategis untuk mengimplementasikan pendidikan transformatif.

Upaya pendidikan yang didasarkan pada pendekatan pendidikan transformatif mengakui pentingnya menginternalisasi nilai-nilai demokrasi. Pendidikan untuk demokrasi membutuhkan proses yang berkelanjutan demi mengubah lingkungan, kognitif, dan konteks pedagogis di mana pembelajaran terjadi. Pada tingkat substansi, pendidikan transformatif mencakup perspektif dan pengalaman kelompok yang secara historis telah terpinggirkan. Praktik pembelajaran transformatif melibatkan peserta didik sebagai pemikir kritis, peserta didik partisipatif, aktif, dan visioner di mana mereka dimungkinan memberikan alternatif solusi pada problematika sosialkemasyarakatan yang selalu berkembang. ${ }^{34}$

Pendidikan transformatif kritis berupaya untuk membantu perkembangan kesadaran individu tentang dirinya sendiri (individual's consciousness of himself or herself) ketika berada dalam situasi kekuatan politik dan ekonomi yang lebih luas. Apa yang disebut Paulo Freire dengan penyadaran (conscientization) adalah proses memberikan fasilitas pemahaman dan pengertian tentang efikasi diri di mana hubungan dominasi dan alienasi dapat diubah. Dengan demikian, tujuan pembelajaran transformatif (transformative learning) bukan sekadar transformasi personal, tetapi juga transformasi sosial, sehingga setiap individu dapat menjadi produsen kreatif bagi diri dan masyarakat dan relasi ekonomi-politik.

Institusi pendidikan memiliki potensi untuk menabur benih penyadaran, wawasan, dan transformasi dengan meningkatkan pemikiran pro-aktif, menggabungkan berbagai perspektif, dan mendorong dialog dan konstruksi pengetahuan. Pembelajaran transformatif dapat menghasilkan perubahan yang signifikan tersebut, jauh jangkauannya, dan berdampak drastis bagi peserta didik. Belenky

34 Ibid.

${ }^{35}$ Lange, “Transformative, 122. 
dan Stanton menekankan bahwa pendidikan transformatif tidak hanya akan mendorong partisipasi dan dukungan dialog reflektif bagi individu peserta didik, namun juga dapat mendukung pembangunan yang lebih inklusif, masyarakat yang adil, dan demokratis. ${ }^{36}$

\section{Penutup}

Kreativitas berpikir dan produktivitas berprilaku dari peserta didik akan berkembang ketika dihadirkan pola pendidikan yang mengaktualisir segenap potensi peserta didik. Kesimpulan itu mengandung arti bahwa pendidikan yang baik dan mampu mengantarkan masyarakat yang demokratis adalah pendidikan yang dikelola dan diarahkan untuk memberikan kemerdekaan bagi peserta didiknya untuk berpikir kritis-kreatif dan berperilaku produktifinovatif dalam menggapai masa depan, sehingga dapat mentransformasikan segenap kemampuan potensi yang dimilikinya serta tidak membeda-bedakan jenis kelamin, suku bangsa, dan agama. Seorang guru dituntut memiliki kemampuan menyerap kebutuhan dan potensi peserta didik serta dapat intens berdialog dengan mereka untuk mempersiapkan bahan yang akan diajarkan. Tentunya upaya itu tidak mudah dan membutuhkan waktu yang tidak pendek. Paling tidak harus ada banyak pihak yang harus terlibat mensukseskan pendidikan model tersebut, terutama bagi masyarakat sendiri sebagai subjek dan objek pendidikan.

\section{Daftar Rujukan}

Azizy, Ahmad Qodri A. Pendidikan (Agama) untuk Membangun Etika Sosial: Mendidik Anak Sukses Masa Depan, Pandai, dan Bermanfaat. Semarang: Aneka Ilmu, 2002.

Azra, Azyumardi. Pendidikan Islam: Tradisi dan Modernisasi Menuju Mellenium Baru. Jakarta: Logos, 2002.

Boer, T. J. De. Târikh al-Falsafah fì al-Islâm. Kairo: Lajnat al-Ta’lîf wa al-Tarjamah, t.th.

Departemen Pendidikan Nasional Republik Indonesia. Undang-undang Republike Indonesia Nomor 20 Tabun 2003 tentang Sistem Pendidikan Nasinal. Jakarta: Biro Hukum dan Organisasi Sekretariat Jenderal Departemen Pendidikan Nasioal, 2003.

\footnotetext{
${ }^{36}$ Daniel J. Glisczinski, “Transformative Higher Education: A Meaningful Degree of Understanding", Journal of Transformative Education, Vol. 5, No. 4 (October 2007), 319-320.
} 
Dewey, John. Culture and Freedom, terj. A. Rahman Zainudin. Jakarta: Yayasan Obor Indonesia, 1998.

-----. Democracy and Educational: An Introduction to the Philosophy of Education. New York: The Macmillan Company, 1964.

Freire, Poulo. Pendidikan Kaum Tertindas, terj. Muhdi Rahayu. Jakarta: LP3ES, 2013.

Glisczinski, Daniel J. "Transformative Higher Education A Meaningful Degree of Understanding", Journal of Transformative Education, Vol. 5, No. 4, October 2007.

Indra, Hasbi, Pendidikan Islam Menuju Globalisasi, Jakarta, PT. Ridamulia, 2005.

Lange, Elizabeth A. "Transformative and Restorative Learning: A Vital Dialectic For Sustainable Societies", Adult Education Quarterly, Vol. 54, Iss. 2, Feb 2004.

Maclellan, James. Philosophy of Education. Englewood Cliffs: PrenticeHall, 1976.

Magnis-Suseno, Franz. Etika Politik. Jakarta: PT. Gramedia, 1994.

Redaktur, Tim. "Pemikiran Plato tentang Negara". Majalah Filsafat Driyakarya, Th. 20, No. 9, 1993/1994.

Miskawayh, Ibn. Tạ̣dhîb al-Akhlâq. Beirut: Manshûrat Dâr alMaktabat al-Hayâh, $1398 \mathrm{H}$.

Moore, Janet. "Is Higher Education Ready for Transformative Learning? A Question Explored in the Study of Sustainability", Journal of Transformative Education, Vol. 3, No. 1, January 2005.

Mulia, Musdah. Muslimah Perempuan Pembaharu Keagamaan Reformis. Bandung: Mizan Media Utama, 2005.

-----. "Pendidikan Berwawsan Gender", al-Hikmah, Vol. 3, No. 4, April 2003.

Nagda, Biren (Ratnesh) A., Gurin, Patricia., Lopez, Gretchen E. "Transformative Pedagogy for Democracy and Social Justice", Journal of Race Ethnicity and Education, Vol. 6, No. 2, July 2003.

Nasution, Harun. Falsafah dan Mistisisme dalam Islam. Jakarta: Bulan Bintang, 1985.

Nata, Abuddin. Filsafat Pendidikan Islam. Jakarta: Logos, 1997.

Sînâ, Ibn. Al-Siyâsah fì al-Tarbîyah. Mesir: Majalah al-Mișrîyah, t.th.

Soedijarto. "Memahami Arah Kebijakan GBHN 1999-2004 tentang Pendidikan sebagai Upaya Mencerdaskan Kehidupan Bangsa dan Membangun Peradaban Negara Bangsa Indonesia", makalah 
seminar nasional, Mencari Paradigma Baru Sistem Pendidikan Nasional Menghadapi Millenium Ketiga. Yogyakarta: IPSI dan Primagama, 1999.

Soedijarto. Pendidikan Nasional sebagai Wabana Mencerdaskan Kebidupan Bangsa dan Membangun Peradaban Negara-Bangsa: Sebuab Usaha Memahami Makna UUD 45. Jakarta: CINAPS, 2000.

Sudarma, Momon. Mengembangkan Keterampilan Berpikir Kreatif. Jakarta: PT. Raja Grafindo Persada, 2013.

Suhelmi. Pemikiran Politik Barat: Kajian Sejarah Perkembangan Pemikiran Negara, Masyarakat, dan Kekuasaan. Jakarta: Darul Falah, 1999.

Surbakti, Ramlan. Memahami Ilmu Politik. Jakarta: PT. Grasindo, 1992.

Suwito dan Fauzan (eds.), Sejarah Pemikiran Para Tokoh Pendidikan. Bandung: PT. Angkasa, 2003.

Taha, Mahmoud Mohamed. Syariah Demokratik, terj. Nur Rachman. Surabaya: Lembaga Studi Agama dan Demokrasi, 1996.

Tambak, Syahraini. Membangun Bangsa Melalui Pendidikan: Gagasan Pemikirn dalam Mewujudkan Pendidikan Berkualitas untuk. Kemajuan Bangsa Indonesia. Yogyakarta: Graha Ilmu, 2013.

Whitehead, Alfred N. The Aims of Education and Other Essays. New York: The Free Press, 1957. 